\title{
Racism and Sexism in Superhero Movies: Critical Race Media Literacy in the Korean High School Classroom
}

\author{
Hyesun Cho \\ Peter Johnson \\ University of Kansas \\ U.S. A.
}

\begin{abstract}
Past research on critical race media literacy (CRML) in multicultural education has primarily focused on identifying ways of fostering critical awareness of racism in the U.S. educational context. This study aims to present a situated account of a CRML pedagogy in the Korean high school classroom where students critique the racial and gender discrimination perpetuated in films. Using qualitative research data, such as teacher interviews and student presentation videos, the current study depicts ways in which Korean female high school students raise critical awareness of racism and sexism with the help of an English-speaking native teacher.
\end{abstract}

KEYWORDS: critical literacy, English as a foreign language, language education, racism, sexism

\author{
Literature Review \\ Researcher Positionality \\ Methodology \\ Findings \\ Implications and Conclusion \\ Note \\ References \\ Author Contact
}

In the current political and social context - there is a strong case for a critical literacy that engages students and young people in a discerning navigation through lifeworlds and social relations saturated by textual representation and discourse, whether face-to-face or written, digital or environmental. This is not an abstract ideal or an impractical task for public schooling. It is a new imperative for survival in what are for many volatile and risky political and media, community and civic environments (Luke, 2018, p. 24).

The present study responds to Luke's call for the imperative of critical literacy pedagogy for educators despite "many volatile and risky political and media, community and civic environments." It explores the operationalization of critical race media literacy (CRML) by a native English-speaking teacher in the Korean high school English classroom. 


\section{Literature Review}

Critical literacy provides the means for learners to approach media and texts of all kinds as opportunities for questioning the systems of power that place their knowledge in a subjugated position, as outlined by Freire (1970) and Luke (2012). The privileging and marginalizing of certain groups within the realms of media and education, and the ability of critical literacy practices to interrogate these practices, was the focus of Lankshear and McLaren's (1993) seminal work in the field.

Critical literacy also includes challenging traditional views of literacy through inclusion of a wide range of media formats and technological innovations that alter both the presentation and the potential range of discourses and the inclusion of popular culture for critique (Alvermann \& Hagood, 2000). Once dominated by written text, literacy has undergone a rapid transformation to include multiliteracies, due largely to the explosive growth of the Internet and digital media (Cope \& Kalantzis, 2009). While the rapid democratization of knowledge and communication platforms has amplified misinformation and social friction, this phenomenon has also allowed learners to express themselves and engage with media on an unprecedented scale (Kellner \& Share, 2005, 2007). New technologies and a new emphasis on openness and egalitarian authorship have paved the way for "new literacies" (Knobel \& Lankshear, 2014). Luke (2012) explained critical literacy as the "use of the technologies of print and other media of communication to analyze, critique, and transform the norms, rule systems, and practices governing the social fields of everyday life" (p. 5).

Critical media projects can also prepare learners to question and challenge dominant cultural narratives displayed in film. Gainer (2010) described such a project, asking middle-school students to critique media portrayals of diverse urban students like themselves and analyze the unspoken messages contained in those portrayals. Additionally, Yosso (2002) explored how film representations of race can "teach" consumers that a certain race is inferior or superior, leading to concrete effects in society. Beyond overtly racist messages, the author found that media microaggressions toward and misrepresentations of cultural groups can desensitize media consumers and reinforce damaging stereotypes. Yosso argued that the effects of this "learning" are pervasive and constant, requiring early exposure to critical media literacy and consistent practice applying it.

As Kellner and Share (2009) argue, critical media literacy skills are "an imperative for participatory democracy" because new technologies and media types have "fragmented, connected, converged, diversified, homogenized, flattened, broadened and reshaped the world" (p. 282). As current media forms have grown increasingly complex and their motives opaquer, educators must prepare learners to question the power structures undergirding the messages they hear on a daily basis. While studies in critical media literacy demonstrate that including discussions of race, gender, and sexuality is important, even sympathetic educators can struggle to implement this in their classrooms. Agodzo (2016) found that educators may feel unprepared to open critical discussions of race in their 
classrooms, frequently believing that the diverse demographics of their classes make such a task unnecessary. Ancillary to this belief, some teachers also expressed "colorblindness" to issues of race, arguing that it was more appropriate to depoliticize topics than to approach them critically.

\section{Teaching Critical Literacy in South Korea}

The body of research into critical literacy in South Korea has been growing as a result of increased recognition of its benefits for learners (Kim \& Cho, 2017; Huh, 2016; Suh \& Huh, 2014). Unlike in more ethnically diverse nations such as the United States, issues surrounding race and critical media literacy in South Korea differ due to the comparative lack of racial diversity within the Korean population. It was not until 2007 that descriptions of Korea as a mono-ethnic society were removed from textbooks, and curricular standards emphasizing multiculturalism in Korea are relatively new (Moon, 2010). However, South Korea has seen a steady increase in the number of foreign residents and children from international marriages. Consequently, the demographic shifts are changing classroom environments nationwide. Kang (2010) argued that, as a reaction to Korea's colonial experiences, a strong form of national identity and solidarity may hamper educational movements toward diversity and multicultural education. Similarly, Watson (2010) stated that clashes over the role of immigrant labor in the neoliberal economic global order have complicated discussions about the meaning of multiculturalism and whether it is a goal to be actively pursued or a condition to be tolerated.

In their study of international students enrolled in South Korean universities, Lee, Jon, and Byun (2017) found evidence of "neo-racism" and "neo-nationalism" against ethnically Chinese students and a perceived preference for students from Western nations. Even though Chinese students made up the vast majority of the international student population, they were also significantly less likely to feel that they were welcome or treated fairly by their South Korean peers. These racialized preferences are mirrored in an analysis of Korean English as a Foreign Language (EFL) textbooks by Lee (2009). In both subtle and blatant ways, Korean EFL textbooks made the concept of "foreign" synonymous with "Western," minimizing the importance of Korea's Asian neighbors and, by extension, the ethnic backgrounds of an increasing number of its learners.

$\mathrm{Na}$ and Kim (2003) pointed to a failure in more traditional East Asian classrooms to choose textbooks that asked learners to examine cultural contexts and make deeper, more meaningful connections through language. Rather, the textbooks examined provided largely grammar-focused, "survival material" ( $p$. 144). Another explanation is that students may be uncomfortable with the shift from teacher to student authority and may respond by resisting that change $(\mathrm{Cho}, 2018)$. Kim (2014) noted that the Confucian tradition might influence Korean students to be reluctant to speak up and challenge the authority in the classroom (Oh-Hwang, 1993). 


\section{Critical Media Literacy in Multicultural Education in Korea}

While critical literacy research in East Asia has been a topic of increased focus recently, research into critical media literacy in Korean classrooms is sparse. Kim (2005) found that the use of media in the Korean English classrooms she observed was not challenging the students to think critically about what they saw represented in the media used by the instructor. This was due largely to a belief that the students' limited language skills would preclude them from interacting with the media at the level necessary for critical reflection, as well as a perceived lack of relevance in the lives of the learners. Lee (2012) also explored the most important features of critical media literacy instruction, urging teachers to interrogate the ideologies behind the language used in media and the social calls to action that take place as a result of analyzing a source critically. Recently, Kim (2019) argued that the need for critical multiculturalism in Korean classrooms was pressing. In particular, integration of critical media literacy into the curriculum would allow learners to challenge potentially negative media stereotypes that may be left unchallenged in a society as ethnically homogenous as South Korea.

Research has thus far primarily examined the theoretical and pedagogical frameworks of critical media literacy in university settings. However, there is a comparative lack of studies looking into the development of critical media literacy in the secondary classroom, where the pressure of standardized testing for university admissions drives curricular choices. Therefore, more research is needed to better understand how teachers support their learners in questioning, appropriating, and evaluating the meanings and purposes of texts using critical race media literacy in the high school classroom. Very few accounts of native English-speaking teacher CRML practices in the English classroom currently exist. This study provides pedagogical examples of these critical literacy practices in the Korean EFL high school classroom.

\section{Researcher Positionality}

In a qualitative study, it is important to reveal researchers' own experiences and positionalities because they shape the ways researchers framed and analyzed the study (Cho, 2018). The researchers' perceptions and interpretations become part of the research, and thus a subjective and interpretive orientation flows throughout the inquiry (Creswell, 2014).

The first author of the present study, born and raised in Korea, worked as a public-school English teacher in Seoul upon graduation from college in Korea with an English language education degree. While teaching middle school students, she attempted to teach English from a critical perspective despite instructional constraints (e.g., "teaching to the test"). For example, she encouraged students to examine the images in the textbook on Thanksgiving by asking questions such as "Who is represented here," "Who is not seen here," "Why are there all Whites, not Blacks or Asian-Americans in this picture?" Her interest in critical literacy pedagogy (Cho, 2018; Kim \& Cho, 2017) led her to develop a faculty-led study abroad internship program with a colleague also teaching at her university in the 
midwestern United States. The study abroad program provides an opportunity for American students to teach English in the Korean secondary classroom while living in a dorm with Korean high school students (Cho \& Peter, 2018). She served as a program director/course instructor/faculty supervisor while working with American student teachers and Korean high school teachers and students.

The second author is a White male originally from the rural Midwest. After obtaining a Master's in TESOL, he taught in a Korean university in credit-bearing English courses and in adult EFL classes through the university's private language programs. As a doctoral student in curriculum and instruction studies at the same university as the first author, he has taught teacher education courses in collaboration with her. He also accompanied the study abroad program to Korea as her graduate teaching assistant in the summer of 2019. Given his time living as an expatriate teacher in Korea, he was able to offer students advice about classroom expectations and the experiences of being a foreign teacher working within the Korean educational context.

\section{Methodology}

This single case study follows the constructivist and interpretivist orientation outlined by Stake $(1995,2006)$. This orientation centers on the subjectivity of reality as a co-creation of the researcher(s) and participant(s). It is, therefore, critical to consider the role the researcher position plays in interpreting the stories provided by the participant(s). According to Stake (1995), vignettes-episodes of storytelling-are recommended to illustrate aspects of the case and thick descriptions to convey findings. Therefore, in this paper, we use student presentations as vignettes to elucidate CRML practice mediated by a teacher of color.

\section{Data Collection and Data Analysis}

During the summers of 2015,2017 , and 2019 when the first author led groups of American students to Korea for six weeks, data were collected from focal teacher interviews, participant observations of his interactions with students both inside and outside the classroom (e.g., hallways), field notes, student presentation recordings, and other documents (e.g., rubrics, textbooks, and teaching materials). Twice each summer, the first author interviewed the teacher, with each interview lasting about an hour. These interviews took place in his classroom after school when nobody was around and there was minimal background noise. The interviews were generally focused on critical literacy but were open-ended and adaptive to the natural flow of the conversation. The teacher was asked about his successes and setbacks in attempting to integrate critical literacy into his classroom, for example. The second author then transcribed the interviews, which were recorded electronically.

Part of a larger study on critical literacy pedagogy in the Korean context, this article primarily draws from interview transcripts and videos of student 
presentations from a visit to the school in the summer of 2019. These data resources were analyzed iteratively to examine the teaching practice and student learning regarding critical race media literacy.

\section{Research Context}

This study occurred in South Korea over six weeks, from May to June 2019. The research site, a private Christian girls' high school named Jinsung (pseudonym), is a selective institution with a track record of success in preparing students for Korea's university entrance examinations. Additionally, Jinsung provides language instruction from native English-speaking teachers and several study abroad programs. It had a student body of roughly 800 at the time, about half of whom board at the school over the course of the school year. Students at the school attended English classes with a native English-speaking expatriate instructor once a week for 50 minutes. This instructional time was in addition to English classes taught by native Korean speakers. The balance of students' time was taken up by standard high school coursework and religious activities.

The study took place within the classroom of one native English-speaking instructor named Doug (pseudonym). A significant aspect of Doug's classes was the development of academic research and presentation skills. The authors were able to observe several final presentations given by students in their second year of study with Doug. The presentations were the culmination of two years of academic English literacy development and rapport building between Doug and his students. As these presentations contributed to their overall English grade as a part of 'performance assessment,' students put considerable effort into writing a script in English, refining their presentation slides with visual images, and practicing public speaking skills.

Student participants were either 15 or 16 years old and were referred to as second-grade students (the equivalent of 11 th grade students in U.S. schools). Doug's class sizes ranged from 22-24 students per session, and Doug taught 24 class sessions per week. As a final project, students were put into pairs; each pair was required to complete a research project and a 7-minute presentation exclusively in English on a topic of their choice. The presentations were recorded by Doug and used for grading purposes. School administrators utilized consent forms in Korean for the use of student presentation data in this study.

\section{Findings}

The following section is presented in two parts. The first part provides a discussion of Doug's personal and educational background and how his experiences related to race inform his philosophy on teaching. Second, two student presentations focused on race in movies are provided as examples of his CRML pedagogy. 
The difficulty in identifying effective approaches to CRML may be partially attributed to the lack of attention to teachers themselves. Research findings that establish the importance of teachers in the achievement of EFL students might be extrapolated to suggest the importance of teachers in critical literacy pedagogy (Metz, 2018). The impact of the background of an educator on their teaching practices cannot be understated either. Multiple studies have demonstrated the effects of teacher background on the development of worldviews, choice of teaching environment and how teachers interact with colleagues and students (Delpit, 1995; Lankford, Loeb, \& Wyckoff, 2002; Weick, 1995).

Doug, the native English-speaking teacher at Jinsung, is a Thai-American heterosexual male in his 30s. At the age of three, he was adopted from Thailand by his American parents, who identify as White, and raised in New York City. He had been teaching English for seven years at Jinsung at the time of the article and for 10 years in Korea in total. Doug lived in housing provided by the school not far from campus with his Thai wife. Although he taught English in Bangkok for five years upon graduation, he did not have formal training in language teaching. However, according to him, it was not his lack of teacher training but his race as a South Asian that inhibited him from getting a teaching position in Korean public schools.

Doug: $\quad$ The first year, it was difficult. I had to prove myself. Everywhere I went in Korea, I had to prove myself just because it was a struggle coming to Korea. You know, because l'm not white. I'm not Korean American. So, I was rejected from so many different schools before I even got a chance. I didn't even think I was going to come to Korea just because it was so hard to get a job....My first recruiter I worked with sent me an email and said "I don't think I'm going to be able to get you a job. You're not white and you're not Korean American."

Researcher: Just based on your ethnicity...

Doug: $\quad$ Yeah, just based on my ethnicity! I had to send a picture to every single school. And I had great interviews! I had great Skype interviews! They would tell me "You're great! You're the type of personality we want! But you don't look like a native speaker." And they would ask me, "What country are you from?" And I would say, "America." And they would say, "No, you're not." Like, oh, ok... Here's my passport! [laughs]

(Interview)

When applying for a teaching job in South Korea, he had to "prove himself" because he was not a "typical White native speaker" whose status and norm was valorized in the Korean EFL context. He attributed the difficulty of job applications as an EFL teacher in Korea to his ethnicity as a South Asian, revealed in his picture in his resume. As attaching a picture of oneself to a resume is a mandatory process of job application in Korea, his racial identity was immediately exposed. Although 
his nationality is American, he was not considered as "the ideal English teacher" by Korean hiring agencies and administrators. The notion of 'nativeness' in language teacher identity is frequently associated with one's race (Ahn, 2019; Grant \& Lee, 2009; Kubota \& Lin, 2009; Motha, 2006). Particularly in Korea, native speakers are covertly and overtly associated with 'whiteness' (Jenks, 2017) as a valued commodity. Doug's own experience as an expatriate teacher in Korea, as well as his upbringing in the United States as a racial minority, seemed to make him cognizant of power imbalances inherent in society.

When Doug finally got a job offer from Jinsung, he was given teacher autonomy in curriculum development and assessment. The Jinsung administration allowed him to develop his own textbook and administer performance assessments. Furthermore, the respect for his pedagogical choices demonstrated by the administration and his colleagues was one of the key factors in his continued job satisfaction, mirroring the findings of Howard's (2019) study of foreign language instructors in Korean classrooms.

Doug: $\quad$ Then I came to [Jinsung] and I had an interview with them, and they told me the structure of the class. That's when I asked them how much creativity I could have in the class. They said you would create your own book. It's a lot of work and you teach a lot of classes... but there are a lot of benefits as well. So that's what attracted me to it.

(Interview)

As Doug recalled, the trust placed in him by Jinsung was a major factor in his ultimately accepting the position. Prior to starting at Jinsung, Doug was developing his own innovative English curriculum (e.g., teaching English through cooking). Therefore, the autonomy to create materials that he felt relevant to his students was important to him. As Yoon (2016) observed in the case studies of seven secondary teachers who attempted to teach critical literacy, a teacher's instruction is mediated by a broader social, political, cultural, and institutional context. When asked more specifically about his educational background, Doug shared his college experience in a liberal arts school in the U.S.

Researcher: What was your major in college?

Doug: It was American Racial and Multicultural Studies.

Researcher: Interesting!

Doug: It was definitely a heavy topic, a heavy major.

Researcher: It was a liberal arts school?

Doug: It was a liberal arts school. So, this was a cross-cultural study of different ethnicities, different populations in America and how they interact in society and how society treats them. So, a lot of times we talked about institutionalized racism... 
Researcher: Microaggressions...

Doug: $\quad$ Yeah, we talked about microaggressions. And America itself was founded on this idea of invasion almost, so a lot of days I was really depressed [laughs]. So, it was definitely hard to get through, but it was very interesting. I was originally in sociology, but I just concentrated a little more.

(Interview)

As Weick (1995) argued about the role of teacher background in pedagogical practice, Doug's worldview and his conception of the role of the teacher is a product of his own educational experiences. Doug attributed his teaching styles to his prior educational experience as a racial minority student. Doug majored in racial and multicultural studies, an area of focus that wrestled with complex and emotionally charged topics, such as systematic racism and microaggressions (Sue, 2010). His background studying the histories of minority groups and racialized power structures heavily influenced his approach to education. This included pushing students to think critically and question the purposes and interests served by what they were learning. Doug's desire was to recreate the educational environment he found so engaging and liberating as a learner, now within his own classroom as a teacher.

Researcher: You're discussing very sensitive topics in the classroom. Nobody would really challenge the teacher and say, "you know, you're wrong." That's not something that we would do here in Korea.

Doug: It's not!

Researcher: Even though they know that the teacher made a mistake, nobody would point it out saying, "you're wrong." It's just taboo.

Doug: $\quad$ Right, right. Very taboo. And that's why my class is so special because I tell them, if I make a mistake, tell me! A lot of my teaching style comes from my background education. We were taught to question.

(Interview)

A significant aspect of Doug's philosophy of education is the democratization of the classroom and the building of trust between student and teacher. Rather than seeking to maintain hierarchical positions in the classroom, Doug actively encourages his students to question and challenge both him and the rationale behind how they are being taught in the classroom. It is this open dialogue that Luke (2012) found central to critical literacy practice. Rather than being teachercentered, Doug hoped to nurture an environment that broke down the traditional banking model of education (Freire, 1970). 


\section{Racial and Gender Issues in Film}

The topics chosen by Doug's students ranged from teen smoking to gender discrimination in the labor market. The following two student presentations are representative data because they discuss the intersection of racism and sexism perpetuated in films. We decided to focus on movies because they represent discourses that are "communicated through different kinds of semiotic resources, different modes," and adolescents "frequently experience these discourses as fun, as style, and simply as part of the taken for granted everyday world, even if on other more or less tangible levels they feel their power over them" (Machin, 2013, p. 347).

The first student presentation focused on representations of race in the superhero movie Black Panther. In their presentation of Black Panther, the students began by presenting the main protagonist and antagonist as representatives of differing aspects of the Black experience. T'Challa, played by Chadwick Boseman, represents the continental African experience while the film's antagonist, Erik "Killmonger" Stevens, represents the experiences of the Black diaspora. Specifically, the presenters argued that Eric "Killmonger" represents the characterization of a Black man growing up within the oppressive racial systems of the United States who problematizes systematic racism against the Black community with advanced weaponry. T'Challa, however, takes a more isolationist view of race relations, arguing that the scientific advancements of his secretive nation should remain hidden. Within the context of the film, the presenters argued that the conflict between these two characters represents the complex and sometimes conflicting identities held by African Americans (Figure 1).

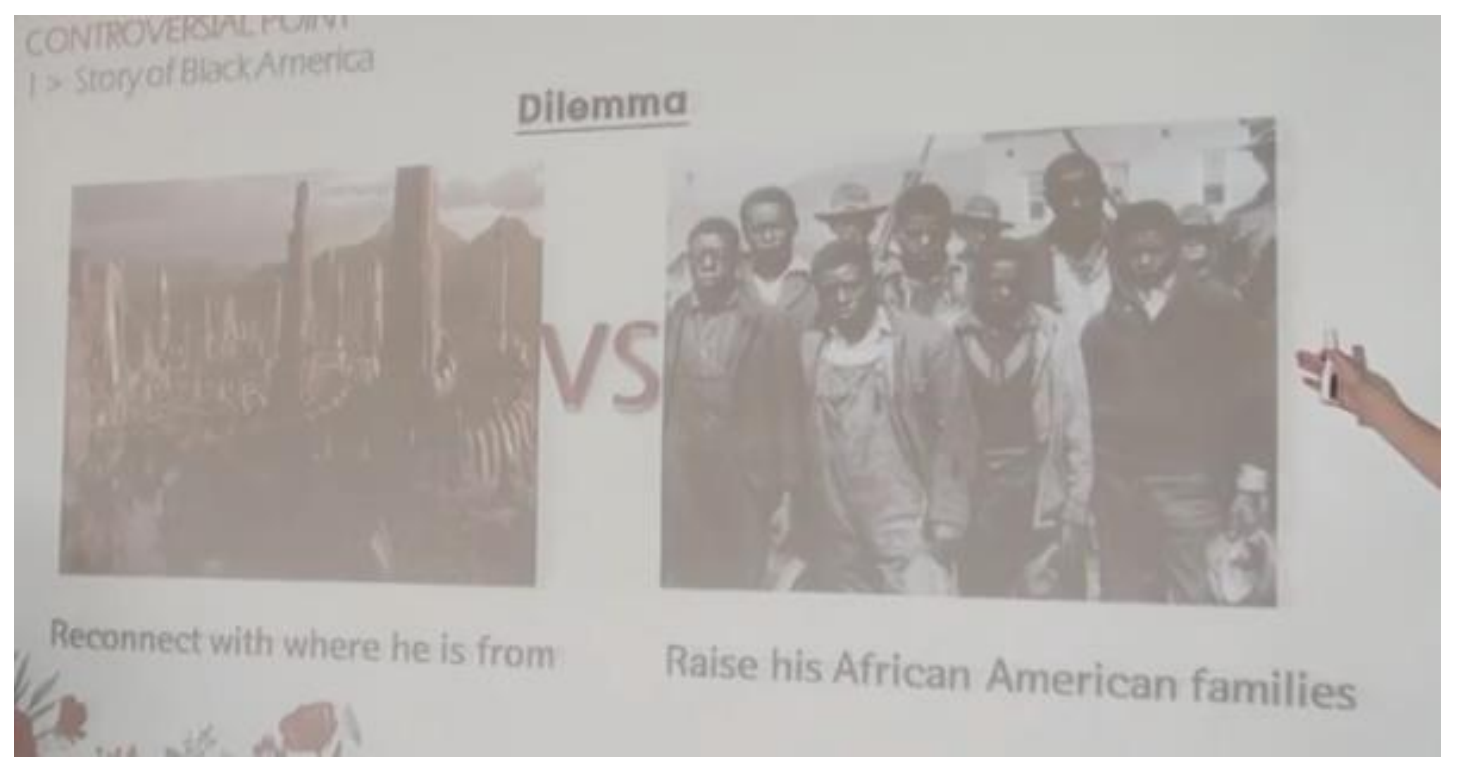

Figure 1. Student portrayal of Erik Stevens' identity dilemma 
The presenters then discussed how other projects of Black Panther director Ryan Coogler explore issues of race, discrimination, and oppression within U.S. society. In his film Fruitvale Station, Coogler depicted the last day of Oscar Grant before his fatal shooting at the hands of an Oakland, California, police officer. By connecting these films together through their director, the students demonstrated that the philosophy of Erik "Killmonger" in Black Panther is a product of his experience dealing with the injustices of U.S. race relations, an experience to which T'Challa cannot relate. This realization serves to complicate the image of Erik "Killmonger" as a mindless villain, casting him as a conflicted, yet justiceseeking, character. The strategy on the part of the presenters to connect the themes of two separate films served to upset the stereotypical racial representations of minority villains in media as described by Yosso (2002) while simultaneously informing the audience about the complex experiences of the U.S members of the African diaspora.

In the second half of their presentation, the students turned to the portrayal of Black women in the film Black Panther. The first point addressed was a short, yet meaningful, video clip shown by the presenters. In the clip, the character Okoye removes a wig and throws it away to fight more effectively. As critically analyzed by the presenters, this moment represented both a moment of racial empowerment and gender empowerment (Figure 2). To the students, the character's removal and disposal of her wig represented a rejection of both racialized and gendered beauty standards in favor of strengthening herself, both literally and figuratively.

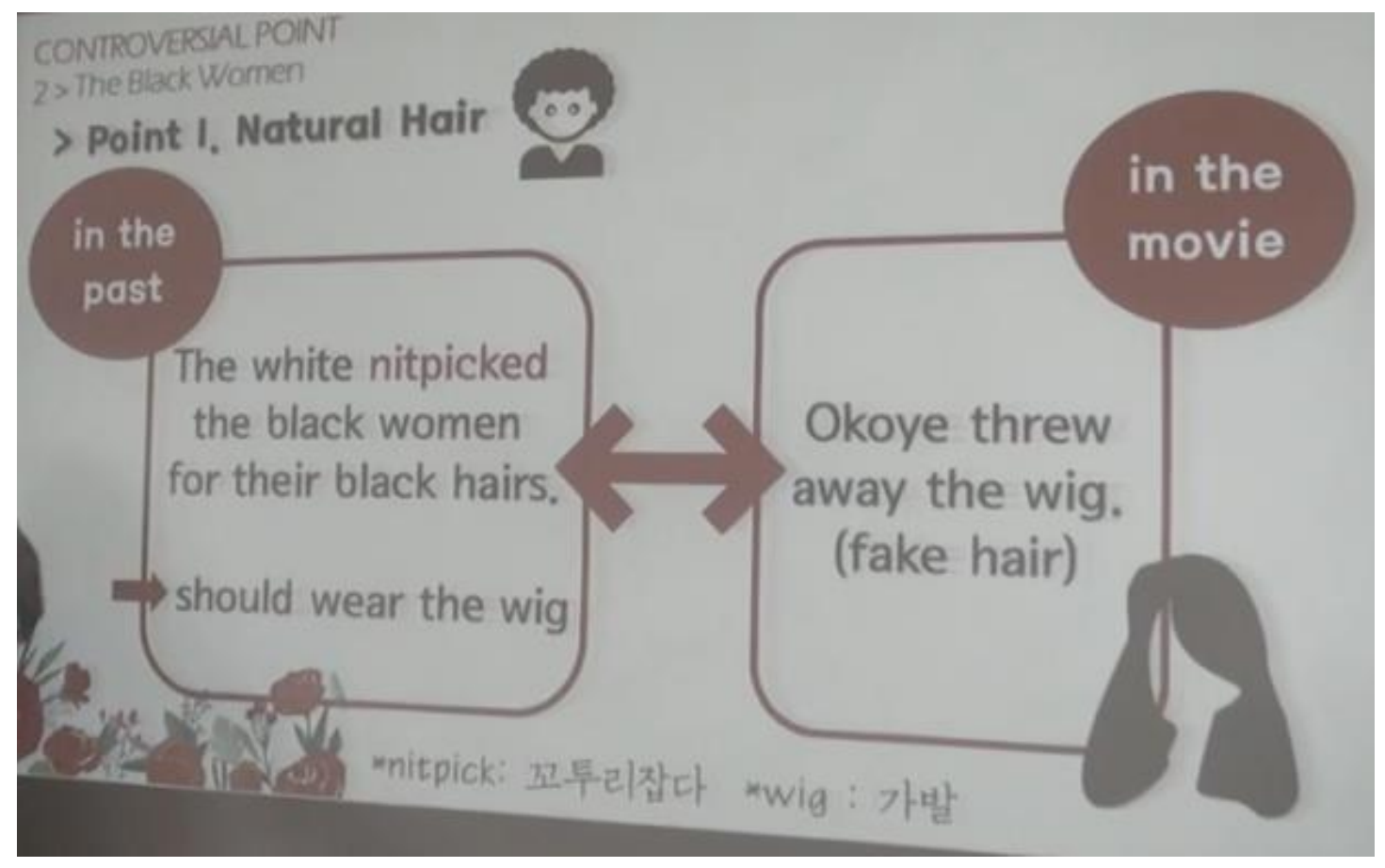

Figure 2. Students explain the social significance of a movie scene 
Finally, the presenters highlighted a moment in which stereotypical portrayals of female characters in film were subverted in Black Panther. When the male character W'Kabi turns against the nation of Wakanda, his girlfriend Okoye is forced to choose between her loyalty to her country and her loyalty to her partner. Contrary to many film portrayals of women as dependent on men for characterization and motivation, Okoye's rejection of W'Kabi due to his betrayal of their nation of Wakanda breaks these stereotypes. As one presenter explains, "In some movies, they say that women are weak for love and should sacrifice for men. However, in this movie, women can kill men, even if he is her lover" (Student presentation).

In their concluding remarks, the presenters poignantly asked their audience to dig deeper into the underlying structures of power (i.e., racism and sexism) that underlie the world we all live in and the media we consume on a daily basis. Through utilization of their bilingualism and multiliteracy skills as shown in Figure 2 , the presenters made the hidden issues of race and gender visible for critique (Esquivel, 2019).

The second student presentation paid more specific attention to issues of racism both toward and among Asian populations. While the first student presentation framed its discussion of racism within the bounds of film, the second presentation utilized cinema as one portion of a larger argument about issues of racism and discrimination faced by Asians. Additionally, the second group of presenters used their analysis to call for action from the audience toward social justice. This format corresponds to Luke's (2012) depiction of critical literacy as both informative and justice-seeking. To begin, the presenters focused on issues of racial stereotypes faced by Asians, including both physical and societal aspects. Harnessing the multimedia format of their presentation, the presenters used an image (Figure 3) to portray what they believed to be a stereotypical characterization of an Asian person from the perspectives of other racial groups. As one of the students argued, "If you ask a white or black person to paint an Asian, some of them look like this. They are long in their eyes! This is a racial stereotype and discrimination" (Student presentation). In this example, the students portrayed the image as an exoticization, with exaggerated, unnatural eye shapes. 


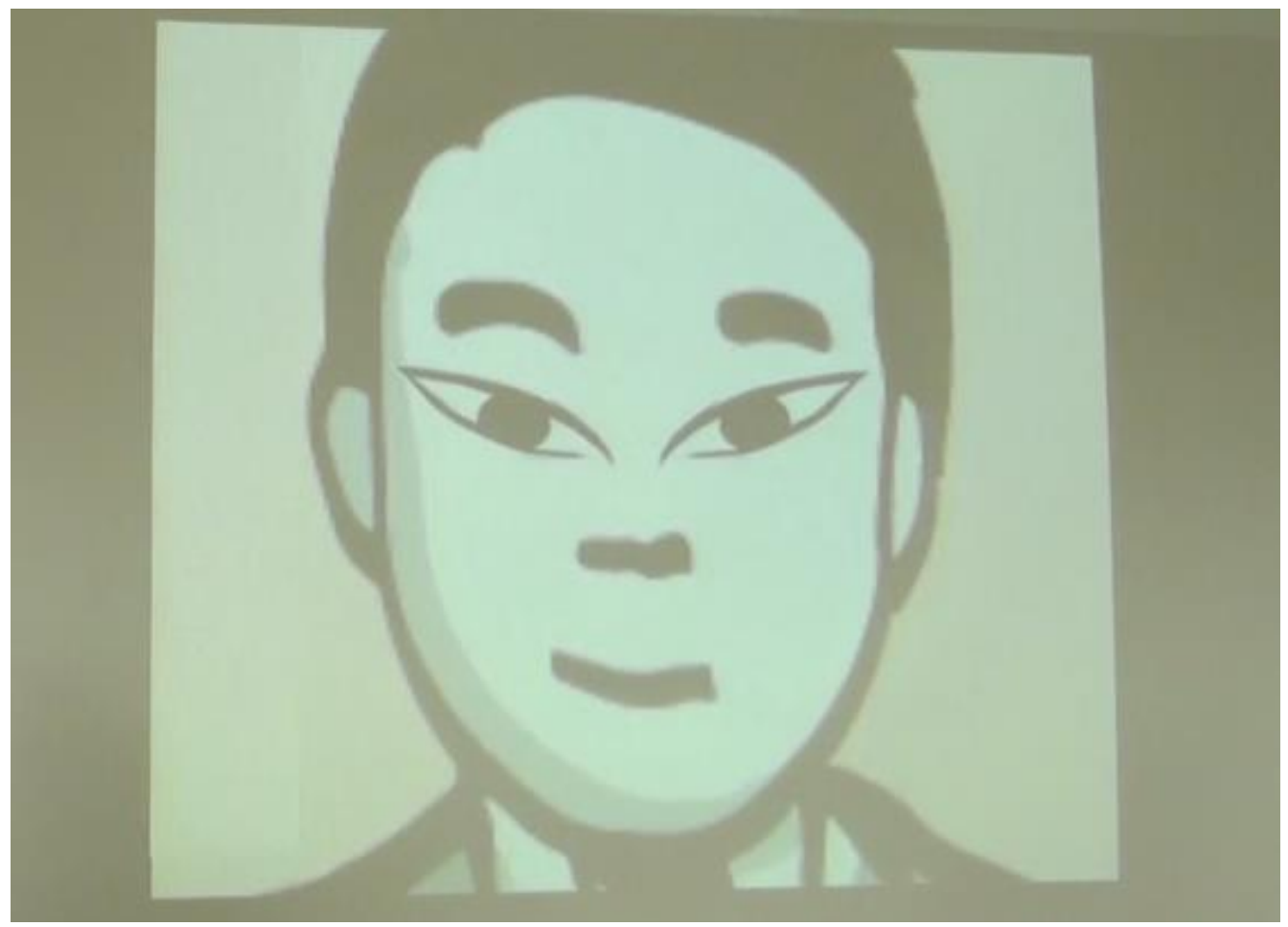

Figure 3. Student representation of a stereotypical "Asian" face

Following their focus on physical stereotypes of Asians, the presenters moved on to argue that there is a stereotypical belief within western nations that Asian societies are inferior and that these beliefs can also replicate themselves between Asian nations based on skin color. As the presenters explained,

Presenter 1: They [western people] think they are superior to Asians. The same is true of racism between Asians. Brighter skin Asians, mainly Northeast Asia, discriminate against darker skin Asians, mainly from Southeast Asia. Why do Asians discriminate against same Asians? It is because of the wrong stereotype, too. Northeast Asians, especially older people, perceive Southeast Asia as a country with poor hygiene, with low economic power, and inferior than their own.

(Student presentation)

While critiquing racism against Asians by people in western countries, students also raised issues of racism within Asian populations. Given that the classroom population was all ethnic Korean, the presenters then pivoted to make the issue more relevant to the all-female audience, arguing that immigrant women within Korea bear the brunt of these stereotypical attitudes. The discrimination toward women from Southeast Asia is, they explained, a result of what they see as transactional marriages between Korean men and Southeast Asian women. They stated, "Especially, Southeast Asian women are placed in blind spots for sex 
crimes. Southeast Asian women suffer from prostitution marriage under the guise of international marriage" (Student presentation). The presenters argued that stereotypes about the illegitimacy of international marriages contributed to the sexualization of Southeast Asian women in Korea more generally.

These findings correspond to the research on immigrants to Korea (Choo, 2016; Moon, 2015). In recent decades, immigration to South Korea, largely from China and Southeast Asia, has increased rapidly. Three waves of immigration have increased the population of foreign-born residents from $0.1 \%$ in 1990 to $3 \%$ in 2015 , with a projected share of the population at $10 \%$ by the year 2030 (Moon, 2015). While the first two waves of migration consisted largely of laborers, the third wave was mainly comprised of women who had arranged to marry lower-class agricultural laborers in the more rural areas of Korea. In 2015, nearly $40 \%$ of all marriages in rural areas were between a Korean man and an immigrant woman (Moon, 2015). Women immigrating to South Korea often face discrimination from neighbors, threats of deportation, spousal abuse and conscription into sex work (Choo, 2016). In addition to immigrant women facing discrimination, the children of international marriages face discrimination as well. Children of such families have high instances of bullying due to their heritage and may even decline scholarships in attempts to keep their family background a secret from others (Chosunilbo, 2012). Recently, negative portrayals of immigrants within Korean popular media and online discussion boards have shown discord regarding government attempts to aid in the resettlement of refugees to Korea (Lee, 2018).

As the students explained, minority women within Korea can face discrimination in wider society, and their presence is often sexualized.

Presenter 2: Southeast Asian women living in Korea are being cat-called by many men. The examples of catcalling are...

Presenter 1: 'Hey, how much are you per hour?', 'Give me some Thai massage.' and 'Ay, can you do that for free?'

Presenter 2: These are based on the prostitution business in Korea. Their human rights are not being ignored; they just don't exist from the beginning in this country. They become good prey to racism.

(Student presentation)

The linguistic distinction regarding women's rights highlights the difference between a more immediate, potentially temporary situation (being ignored) and a more permanent condition (not existing from the beginning) that is a result of social structures (Lee, 2012). Identifying this distinction also provides an opportunity for the presenters to frame the lack of legal protections against racial discrimination as a site for future social justice work (Luke, 2012).

In addition to appeals to gender to make the topic more relevant for the audience, the presenters used popular cinema as a way to highlight racial discrimination towards Asians in a way that harnessed their audience's 
background knowledge. Earlier in the presentation, the students had argued that racism against Asians often gets entirely ignored or treated with less sensitivity than racism against other racial groups, such as Blacks in the U.S. This downplaying of the significance of racist actions toward Asians is, they posited, its own form of discrimination. To demonstrate this, the presenters focused on the superhero film "Dr. Strange," which had just been released in theaters. To begin, the presenters broached the topic of "whitewashing" to the audience, defining it as "painting dirty places with white paint or hiding defects." The students then introduced the second meaning of the term in relation to popular media, stating, "Nowadays, it means a white actor acts as an Asian character, unlike the original. Asians are erased and replaced easily in content business such as movies or drama" (Student presentation). Here, the presenters deftly drew the comparison for their audience, highlighting the connection between the whiteness of Caucasian actresses and actors and the paint, as well as the connection of Asian actresses and actors to their linguistic choices of the words "dirty" and "defects."

Continuing, the students projected the image of Tilda Swinton in the movie "Dr. Strange" (Figure 4).

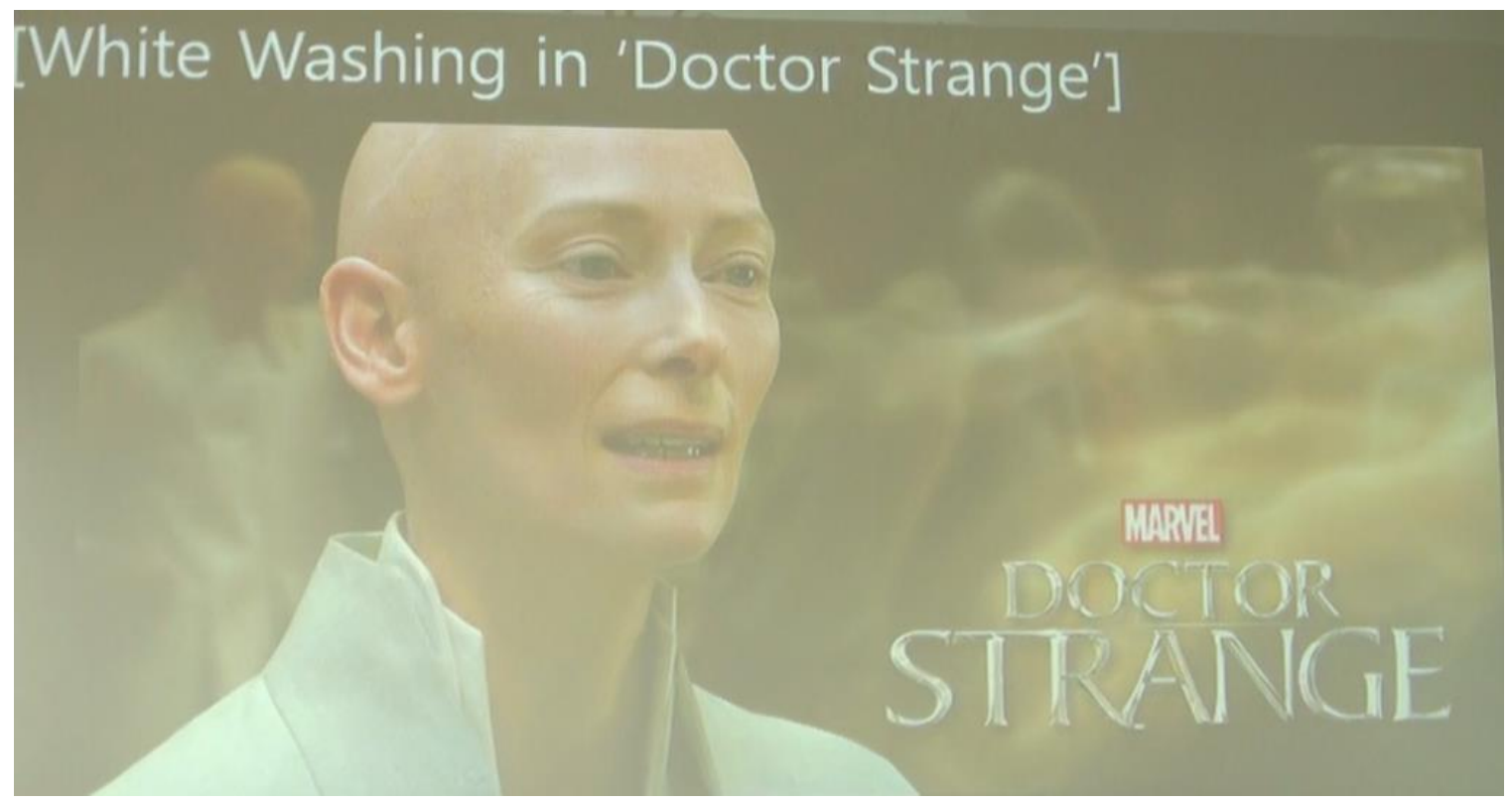

Figure 4. Students present a "whitewashed" film role

Following the projection of the image, the presenters took a moment to interact with the audience:

Presenter 2: Did you guys watch Dr. Strange?

Class: [Cheers of 'yes!' from the audience]

Presenter 2: There is whitewashing. Do you know her? 
Class: Yeah.

Presenter 1: Yeah, it's Tilda Swinton!

Student 1: I love her movies!

Presenter 2: Her role as 'ancient one' is Tibetan, but she is definitely white! It is racial discrimination and hatred that erase the existence of Asians.

(Student presentation)

The complexity of the interaction between the presenters and audience can be seen in the above excerpt. On the one hand, the audience shared a clear affinity for the film, and one audience member even expressed her admiration for the actress playing the role that the presenters accused of being whitewashed. On the other hand, the presenters were connecting the whitewashing in the film to the same discriminatory action shown by the minimization of the possibility that Asians could be the targets of racist stereotypes. In essence, the presenters argued that the erasure of Asian struggles with discrimination has a direct connection to the comparative ease with which they are "erased" from film roles through the casting of White actors and actresses in clearly Asian roles. These same concerns received some U.S. media coverage, including Emma Stone's role in the film Aloha (Nguyen, 2015), as well as Matt Damon's part in The Great Wall (Nguyen, 2017).

Underpinning much of this scholarship is the notion that understanding the relationships between youth, media literacy, and popular cultures provides powerful opportunities to facilitate young people's critical awareness of the intersection of racism and sexism embedded in the media and in society (Tisdell, \& Thompson, 2007). Specifically, youth engagement with popular culture such as movies may provide multicultural educators with opportunities to create safe spaces for students (Gutierrez, 2008; Kirkland, 2008).

\section{Implications and Conclusion}

This study challenges prevailing assumptions about lack of CRML practices in the East Asian context due to students' low English proficiency levels and their cultural backgrounds. Korean high school students in this study were capable of interrogating social issues and presenting their research in a multimodal format to their peers. The student presenters in this study purposefully appropriated superhero movies---Black Panther and Doctor Strange---to delve into the structures of power relations in racism and sexism manifested in media. Through utilization of their bilingual and multiliteracy skills, the presenters made the hidden issues of race and gender explicit for critique among their classmates (Esquivel, 2019).

Findings also reveal that the teacher's instantiations of critical literacy were likely influenced by a myriad of reasons, such as his personal and educational backgrounds, his racialized identity, and the institutional context in which he was free from preparing students for the college entrance exam. By encouraging students to choose a research topic of their interest and helping them present their 
critical perspectives of social issues around them, the teacher promoted 'problemposing' (Freire, 1970) with students to unravel imbalanced power relations embedded in society through media.

A limitation of the present study is due to the tight time schedule allotted for the student presentations. Students were unable to give significant feedback to their peers following each presentation, including being unable to interrogate the reasons behind their peers' choices for the topics of their presentations. Further, the authors did not get a chance to ask the student presenters about how Doug's racial identity may have specifically influenced their topic choices. Exploring these reasons would be an avenue of future research.

There is a need for further research in classrooms in which teachers promote CRML with the use of movies and other multimodal forms of meaning making to engage students with social critique. We also need longitudinal data to provide greater insight into the impact of CRML on student learning and increased support for a multicultural education curriculum that includes CRML. Our belief is that CRML lessons that allow students to interrogate social issues should be a visible component of all curricular engagements, not only in Western classrooms but also in East Asian educational settings. Despite the challenges posed by a lack of empirical studies in this area, it is hoped that this study will help dispel notions that Korean students are less capable of doing CRML work than their western counterparts. With sustained support and clear guidance from a critically minded teacher like Doug, development of the skills necessary to enact CRML in the Korean high school classroom is feasible. Bringing CRML into multicultural education settings, thereby engaging youth in critical conversations about social issues such as racism, is not just "an impractical task for public schooling" as Luke (2018) argues in the beginning of this paper. Rather, it is a "new imperative for survival"(p. 24) in the current racially contested world with the ubiquitous exposure to media and popular culture among adolescents.

\section{Note}

This investigation was supported by the University of Kansas, School of Education Research Support Program.

\section{References}

Agodzo, D. (2016). "Burying their heads in the sand": Critical race media literacy \& Surrey School District teachers. Multicultural Education, 24(1), 25-30.

Ahn, S. (2019). Decoding "good language teacher"(GLT) identity of native-English speakers in South Korea. Journal of Language, Identity \& Education, 18(5), 297-310.

Alvermann, D. E., \& Hagood, M. C. (2000). Critical media literacy: Research, theory, and practice in "new times". The Journal of Educational Research, 93(3), 193-205. 
Cho, H. (2018). Critical literacy pedagogy for bilingual preservice teachers: Exploring social identity and academic literacies. Springer.

Cho, H., \& Peter, L. (2017). Taking the TESOL practicum abroad: Opportunities for critical awareness and community-building among preservice teachers. In H. An (Ed.), Efficacy and implementation of study abroad programs for P-12 teachers (pp. 149-171). IGI Global.

Choo, H. (2016). Decentering citizenship: Gender, labor and migration rights in South Korea. Stanford University Press.

Cope, B., \& Kalantzis, M. (2009). "Multiliteracies": New literacies, new learning. Pedagogies: An International Journal, 4(3), 164-195.

Creswell, J. (2014). Research design: Qualitative, quantitative and mixed methods approaches. SAGE.

Delpit, L. (1995). Other people's children: Cultural conflict in the classroom. New Press.

Esquivel, J. (2019). Embodying critical literacy in a dual language classroom: Critical discourse analysis in a case study. Critical Inquiry in Language Studies, 1-22. doi.org/10.1080/15427587.2019.1662306

Freire, P. (1970). Pedagogies of the oppressed. Continuum.

Gainer, J. S. (2010). Critical media literacy in middle school: Exploring the politics of representation. Journal of Adolescent \& Adult Literacy, 53(5), 364-373.

Grant, R. A., \& Lee, I. (2009). The ideal English speaker: A juxtaposition of globalization and language policy in South Korea and racialized language attitudes in the United States. In R. Kubota \& A. Lin (Eds.), Race, culture, and identities in second language education: Exploring critically engaged practice (pp. 44-63). Routledge.

Gutierrez, K. (2008). Developing sociocritical literacy in the third space. Reading Research Quarterly, 43(2), 148-164.

Howard, N. J. (2019). Constructing professional identities: Native Englishspeaking teachers in South Korea. The Qualitative Report, 24(7), 14781510.

Huh, S. (2016). Instructional model of critical literacy in an EFL context: Balancing conventional and critical literacy. Critical Inquiry in Language Studies, 13(3), 210-235.

Jenks, C. J. (2017). Race and ethnicity in English language teaching: Korea in focus. Multilingual Matters.

Kang, S.-W. (2010). Multicultural education and the rights to education of migrant children in South Korea. Educational Review, 62(3), 287-300.

Kellner, D., \& Share, J. (2005). Toward critical media literacy: Core concepts, debates, organizations, and policy. Discourse: Studies in the Cultural Politics of Education, 26(3), 369-386. 
Kellner, D., \& Share, J. (2007). Critical media literacy is not an option. Learning Inquiry, 1(1), 59-69.

Kellner, D., \& Share, J. (2009). Critical media education and radical democracy. In M. Apple, W. Au, \& L. A. Gandin, The Routledge international handbook of critical education (pp. 281-295). Routledge.

Kim, M. (2019). A critical multicultural approach to Korean English education for socially just diversity. OMNES: The Journal of Multicultural Society, 9(2), 78-99.

Kim, M.-H. (2005). A study on the necessity of critical media literacy in EFL university classrooms. STEM Journal, 6(1), 131-156.

Kim, S. J. (2014). Possibilities and challenges of early critical literacy practices: Bilingual preschoolers' exploring multiple voices and gender roles. Journal of Early Childhood Research, 14(4), 370-388.

Kim, S., \& Cho, H. (2017). Reading outside the box: Exploring critical literacy with Korean preschoolers. Language and Education, 31(2), 110-129.

Kirkland, D. E. (2008). "The rose that grew from concrete": Postmodern Blackness and new English education. The English Journal, 97(5), 69-75.

Knobel, M., \& Lankshear, C. (2014). Studying new literacies. Journal of Adolescent \& Adult Literacy, 58(2), 97-101.

Kubota, R., \& Lin, A. (2009). Race, culture, and identities in second language education: Exploring critically engaged practice. Routledge.

Lankford, H., Loeb, S., \& Wyckoff, J. (2002). Teacher sorting and the plight of urban schools: A descriptive analysis. Educational Evaluation and Policy Analysis, 24(1), 37-62.

Lankshear, C., \& McLaren, P. (1993). Critical literacy and the postmodern turn. In C. Lankshear \& P. McLaren, Critical literacy: Politics, praxis, and the postmodern (pp. 379-420). SUNY Press.

Lee, C. (2018, November 8). Human rights report says Korea has 'serious racism problem'. Retrieved from The Korea Herald: http://www.koreaherald. com/view.php?ud=20181108000721

Lee, I. (2009). Situated globalization and racism: An analysis of Korean high school EFL textbooks. Language \& Literacy, 11(1), 1-14.

Lee, J., Jon, J.-E., \& Byun, K. (2017). Neo-racism and neo-nationalism within East Asia: The experiences of international students in South Korea. Journal of Studies in International Education, 21(2), 136-155.

Lee, J.-H. (2012). EFL instruction procedures for critical media literacy. The Journal of Studies in Language, 28(2), 305-328.

Luke, A. (2012). Critical literacy: Foundational notes. Theory Into Practice, 51, 411. 
Luke, A. (2018). Critical literacy, schooling, and social justice: The selected works of Allan Luke. Routledge.

Machin, D. (2013). What is multimodal critical discourse studies? Critical Discourse Studies, 10(4), 347-355.

Metz, M. (2018). The role of teacher educators' personal histories and motivations in shaping opportunities to learn about social justice. Teachers College Record, 120(7), 1-34.

Moon, K. H. (2015). South Korea's demographic changes and their political impact. Brookings Institution: Center for East Asian Policy Studies.

Moon, S. (2010). Multicultural and global citizenship in the transnational age: The case of South Korea. International Journal of Multicultural Education, 12(1), 1-15.

Motha, S. (2006). Racializing ESOL teacher identities in U.S. K12 public schools. TESOL Quarterly, 40(3), 495-518.

$\mathrm{Na}, \mathrm{Y} .$, \& Kim, S. (2003). Critical literacy in the EFL classroom. English Teaching, $58(3), 143-163$.

Nguyen, K. (2017, February 16). With The Great Wall, Hollywood has made whitewashing China's problem. Retrieved from GQ.com: https://www.gq.com/story/the-great-wall-whitewashing

Nguyen, M. (2015, June 2). Aloha film attacked for 'white-washing' of Hawaii. Retrieved from: http://www.msnbc.com/msnbc/aloha-film-attacked-whitewashing-hawaii.

Oh-Hwang, Y. (1993). Linkage between home environments, child psychosocial maturity, and child academic achievement. Gifted International, 8(1), 32-37.

Stake, R. E. (1995). The art of case study research. SAGE.

Stake, R. E. (2006). Multiple case study analysis. Guilford.

Sue, D. W. (2010). Microaggressions in everyday life: Race, gender, and sexual orientation. John Wiley \& Sons.

Suh, Y., \& Huh, S. (2014). Possibilities and challenges of a critical approach to reading instruction with Korean university students. 영어교육연구 [English Education Research], 26, 39-62.

The Chosunilbo. (2012, January 11). Multicultural children still face discrimination. Retrieved from The Chosunilbo: http://english.chosun.com/site/data/ html_dir/2012/01/11/2012011101030.html

Tisdell, E. J., \& Thompson, P. M. (2007). 'Seeing from a different angle': The role of pop culture in teaching for diversity and critical media literacy in adult education. International Journal of Lifelong Education, 26(6), 651-673. 
Watson, I. (2010). Multiculturalism in South Korea: A critical assessment. Journal of Contemporary Asia, 40(2), 337-346.

Weick, K. (1995). Sensemaking in organizations. SAGE.

Yoon, B. (2016). Critical literacies: Global and multicultural perspectives. Springer.

Yosso, T. (2002). Critical race media literacy: Challenging deficit discourse about Chicanas/os. Journal of Popular Film \& Television, 30(1), 52-62.

\section{Author Contact}

Hyesun Cho, Ph.D.hcho@ku.edu

Peter Johnson johnsonps@ku.edu

Department of Curriculum and Teaching, University of Kansas

1122 W. Campus Rd. JRP Rm 311, Lawrence, KS 66045, U.S.A. 